\title{
Lignite oxidative desulphurization: notice 3 -process technological aspects and application of products
}

\author{
Volodymyr Gunka $^{1}$ (D) Mariia Shved $^{1} \cdot$ Yuriy Prysiazhnyi $^{1} \cdot$ Serhiy Pyshyev $^{1} \cdot$ \\ Denis Miroshnichenko ${ }^{2}$
}

Received: 22 February 2018/Revised: 31 August 2018/Accepted: 29 November 2018/Published online: 11 December 2018

(C) The Author(s) 2018

\begin{abstract}
The study reviews the process of oxidative desulphurization of high-sulphur Ukrainian lignite, which was performed by coal treatment using an air or air-steam mixture. In the process, sulphur-free fuel and tar from the decomposition of coal organic matter was obtained. Hence, the sulphur in the coal was converted into hydrogen sulphide. The coal desulphurization process is critical to power generation, power generation and technology, and technology field of application. The coal desulphurization process ensures the maximum recovery of the highest content of sulphur and hydrogen sulphide $\left(\mathrm{H}_{2} \mathrm{~S}\right)$ in desulphurized gases at minimal energy costs. The process also enhances the maximum decomposition of tar and sulphur recovery $(>50 \%)$ during coal power generation. Based on summarized field studies, a block schematic diagram coupled with heat and material balances of the process was developed for the calculations. The application of the technology at the first stage of coal combustion in thermal power plants will enable the utilization of over $50 \%$ of recovered coal sulphur in the form of concentrated $\mathrm{H}_{2} \mathrm{~S}$ or commercial elemental sulphur. This will, nevertheless, allow for a reduction of sulphur oxide pollution in the environment by at least 53\%-56\%. It has been suggested that the product of thermal decomposition of coal organic matter (tar) can be used as a component of furnace fuel oil or as a plasticizer of petroleum-based road bitumen.
\end{abstract}

Keywords Lignite $\cdot$ Oxidative desulphurization $\cdot$ Sulphur $\cdot$ Hydrogen sulphide

\section{Introduction}

Coal provides $30 \%$ of global primary energy needs and generates over $41.1 \%$ of the world's electricity. It is also used in the production of over $70 \%$ of the world's steel. (http://www.worldcoal.org). However, on-site facilities for generating thermal and electric energy at thermal power plants (TPP) are main environmental emitters of sulphur oxide (IV) (www.eea.europa.eu). This is primarily due to fact that coal is a critical raw material of TPP which

Volodymyr Gunka

vgunka@gmail.com

1 Lviv Polytecnic National University, 12 Bandery Str., L'viv 79013, Ukraine

2 National Technical University "Kharkiv Polytechnic Institute”, 2 Kyrpychova Str., Kharkiv 61002, Ukraine compared to other hydrocarbon fuels (gas, fuel oil) is characterized by the high content of sulphur.

In 2015 , lignite mining was $1.9 \%$ of the total amount of fossil fuels (in contrast with hard coal-31.4\%) (https:// www.bgr.bund.de). This is mainly due to the poor quality of lignite, particularly its high sulphur and moisture content. For example, Ukrainian lignite is characterized by the sulphur content of 3.5\%-4.2 wt\% and moisture of 50\%$60 \mathrm{wt} \%$ with respect to a work sample (Dolgyi et al. 2001). To solve the problem of $\mathrm{SO}_{2}$ emission while burning lignite, one of the directions of possible development of the coal industry could be the ramp-up of coal use for the generation of thermal and electric energy.

The scientists of the Department of Chemical Technology of Oil and Gas Processing at Lviv Polytechnic National University were involved in a detailed study of the desulphurization process of various types of black coal: low-metamorphized coal (Pysh'yev et al. 
2004, 2017a, 2018; Bratychak et al. 2004), mediummetamorphized coal (Pyshyev et al. 2014a, b, 2017a, b), high-metamorphized coal, including anthracite (Shevchuk et al. 2007; Pyshyev et al. 2012a).

Considering extensive reserves of lignite both in the world and in Ukraine (Dolgyi et al. 2001), there has also been an attempt to desulphurize lignite by oxidation method for its further use in the energy sector. In the previous studies (Pysh'yev et al. 2011; Gunka and Pyshyev 2014, 2015), the best values limits of the factors of the oxidative desulphurization process were defined: the oxidant linear rate-0.0125-0.01875 m/s, coal grain size-up to $0.75 \mathrm{~mm}$, temperature -425 to $450{ }^{\circ} \mathrm{C}$, ratio between oxidant volumetric flow rate and coal mass-nearly $0.6 \mathrm{~m}^{3} /(\mathrm{h} \mathrm{kg})$, process duration-5 to $10 \mathrm{~min}$. Additionally, it has been determined that lignite desulphurization for the purpose of its further utilization in TPPs (the energy sector) can be performed only with the use of air. However, to increase the content of $\mathrm{H}_{2} \mathrm{~S}$ in desulphurized gases (an area of power-generation and technology), using as an oxidant air-steam mixture is preferable compared to air is a good practice.

Under the above conditions, the transformation of lignite sulphur, basically pyritic one, into hydrogen sulphide, and partial gasification along with the oxidation of coal organic matter of TPP takes place (Pyshyev et al. 2012c; Gunka and Pyshyev 2014, 2015). In this case, desulphurized gases with a high concentration of hydrogen sulphide are obtained, which can be concentrated or treated to yield sulphur.

This work aims to summarize previous studies on lignite desulphurization by the oxidation method, and on their basis to:

- Create a flow sheet;

- Estimate material and heat balances;

- Suggest possible ways of using main and by-products in practice.

\section{Experimental}

The sample of lignite for investigation was taken from the Morozivske coal-field of Dnipro lignite basin. The fraction of $0.1-0.25 \mathrm{~mm}$ was used for researches because it is the optimum size for coal burning at thermal power. The technical analysis was carried out, and different sulphur forms such as organic sulphur $\left(S_{\mathrm{o}}^{\mathrm{d}}\right)$, pyritic sulphur $\left(\mathrm{S}_{\mathrm{p}}^{\mathrm{d}}\right)$ and sulphate sulphur $\left(\mathrm{S}_{\mathrm{SO}_{4}}^{\mathrm{d}}\right)$ were determined. The results are given in Table 1.

The investigations were conducted on the laboratory plant based on fluidized bed reactor that functioned in the
Table 1 Characteristics of lignite

\begin{tabular}{|c|c|c|}
\hline Index & Value & Procedure* \\
\hline Fraction (mm) & $0.1-0.25$ & - \\
\hline $\begin{array}{l}\text { Moisture, } \mathrm{W}^{\mathrm{af}} \\
\quad(\operatorname{mass} \%)\end{array}$ & 14.0 & GOST 11014:2001 \\
\hline Ash, $\mathrm{A}^{\mathrm{d}}(\operatorname{mass} \%)$ & 9.4 & GOST 11022:95 (ISO 1171-97) \\
\hline $\begin{array}{l}\text { Volatility, } V^{\text {daf }} \\
\text { (mass\%) }\end{array}$ & 63.8 & $\begin{array}{l}\text { GOST 6382-2001 (ISO } \\
562: 1998 \text { ) }\end{array}$ \\
\hline \multicolumn{3}{|c|}{ Sulphur content (mass\%) } \\
\hline Total, $S_{t}^{d}$ & 4.28 & $\begin{array}{l}\text { DSTU 3528:1997 (ISO } \\
\text { 334:1992) }\end{array}$ \\
\hline Pyritic, $S_{p}^{d}$ & 2.10 & $\begin{array}{l}\text { GOST 30404:2000 (ISO } \\
\text { 157:1996) }\end{array}$ \\
\hline Organic, $S_{o}^{d}$ & 2.06 & \\
\hline Sulphate, $S_{S_{4}}^{d}$ & 0.11 & \\
\hline
\end{tabular}

*DSTU and GOST_-Ukrainian national standards

mode close to isothermal. The scheme of the laboratory plant and its detailed description are presented in Pyshyev and Hayvanovych (1996).

The desulphurized gases were analyzed by means of gas-adsorptive chromatography, using a chromatograph "LHM" (N 479). The analyzed gas $(10.0 \mathrm{~mL})$ is introduced by a metering device into the flow of gas carrier (helium). The gas was fed to the first column (diameter of $2.0 \mathrm{~mm}$ and length of $3.0 \mathrm{~m}$ ) filled with a non-polar sorbent Polysorb-1 and then to the second column (diameter of $2.0 \mathrm{~mm}$ and length of $4.5 \mathrm{~m}$ ) filled with a polar adsorbent zeolite of CaX type (Pyshyev et al. 2012a; Gunka and Pyshyev 2014, 2015).

The calorific value was determined on the calorimeter LECO AC-350 in compliance with the standard document GOST 147:1995 (ISO 1928:1976).

The linear oxidant rate (OLR) is calculated as a ratio of oxidant volumetric flow rate $\left(\mathrm{m}^{3} / \mathrm{s}\right.$ under the normal conditions) to the sectional area of an empty reactor $\left(\mathrm{m}^{2}\right)$.

To characterize the oxidant consumption, the term "repetition factor of oxidant flow rate" (OFR) was used. The OFR was calculated as the ratio between the volumetric flow air-steam mixture $\left(\mathrm{m}^{3} / \mathrm{h}\right)$ and the coal mass $(\mathrm{kg})$.

To characterize the relative rate of sulphuric compounds conversion, we used the term "sulphur conversion (SC)". This value indicated the amount of sulphur converted into gaseous sulphur-containing products that will not be in the atmosphere while further burning desulphurized coal (the level of environmental pollution decrease). It is calculated in accordance with the formula (1) \%: 
$\mathrm{SC}=\frac{\mathrm{S}_{0}^{\mathrm{a}} \cdot 100-\mathrm{S}^{\mathrm{a}} \cdot \mathrm{x}_{\mathrm{C}}}{\mathrm{S}_{0}^{\mathrm{a}}}$

where $\mathrm{S}_{0}^{\mathrm{a}}$ - the content of sulphur in the initial coal relative to the analytical sample (wt\%); $\mathrm{S}^{\mathrm{a}}$ - the content of sulphur in the desulphurized coal relative to the analytical sample $(\mathrm{wt} \%) ; \mathrm{x}_{\mathrm{C}}$-the yield of desulphurized coal (wt $\%$ ).

The sulphur content in the desulphurized coal depends on the ratio between the conversion rates of the coal and pyritic sulphur in it. Hence, the removal degree of sulphur (RDS) is calculated in accordance with the Eq. (2) and indicates the ratio between the rate of sulphur conversion followed by the production of gaseous products and the rate of organic matter reaction, i.e. process selectivity:

$\operatorname{RDS}=\frac{S_{\mathrm{o}}^{\mathrm{d}}-\mathrm{S}^{\mathrm{d}}}{\mathrm{S}_{\mathrm{o}}^{\mathrm{d}}} \cdot 100$

where $S_{0}^{\mathrm{d}}$ - the content of sulphur relative to the dry sample (wt \%); $\mathrm{S}^{\mathrm{d}}$ - the content of sulphur in the desulphurized coal relative to the dry sample (wt $\%$ ).

The thermal effect of the oxidative desulphurization of lignite was estimated according to the formula, MJ:

$\mathrm{Q}_{\mathrm{r}}=$

$\frac{\mathrm{G}_{\mathrm{H}_{2} \mathrm{~S}} \cdot \mathrm{q}_{\mathrm{r}}^{\mathrm{H}_{2} \mathrm{~S}}+\mathrm{G}_{\mathrm{CO}} \cdot \mathrm{q}_{\mathrm{r}}^{\mathrm{CO}}+\mathrm{G}_{\mathrm{CO}_{2}} \cdot \mathrm{q}_{\mathrm{r}}^{\mathrm{CO}_{2}}+\mathrm{G}_{\mathrm{H}_{2} \mathrm{O}} \cdot \mathrm{q}_{\mathrm{r}}^{\mathrm{H}_{2} \mathrm{O}}+\mathrm{G}_{\mathrm{r}} \cdot \mathrm{q}_{\mathrm{r}}^{\mathrm{r}}}{1000}$,

where $\mathrm{G}_{\mathrm{H}_{2} \mathrm{~S}}, \mathrm{G}_{\mathrm{CO}}, \mathrm{G}_{\mathrm{CO}_{2}}, \mathrm{G}_{\mathrm{H}_{2} \mathrm{O}}, \mathrm{G}_{\mathrm{r}}$ are the amount of sulphur, $\mathrm{kg}$, that is converted to hydrogen sulphide; carbon burned to $\mathrm{CO}$; carbon burned to $\mathrm{CO}_{2}$; hydrogen burned to $\mathrm{H}_{2} \mathrm{O}$; the amount of decomposition tar, respectively. These quantities (except for $\mathrm{G}_{\mathrm{H}_{2} \mathrm{O}}$ ) were assessed on the basis of the material balances and the contents of desulphurized gases; $\mathrm{q}_{\mathrm{r}}^{\mathrm{H}_{2} \mathrm{~S}}, \mathrm{q}_{\mathrm{r}}^{\mathrm{CO}}, \mathrm{q}_{\mathrm{r}}^{\mathrm{CO}_{2}}, \mathrm{q}_{\mathrm{r}}^{\mathrm{H}_{2} \mathrm{O}}, \mathrm{q}_{\mathrm{r}}^{\mathrm{r}}$ denote the thermal effects of corresponding reactions, $\mathrm{kJ} / \mathrm{kg}$.

The amount of hydrogen $(\mathrm{H})$, converted to $\mathrm{H}_{2} \mathrm{O}$ during combustion of coal organic matter (COM), was calculated assuming that the ratio of $\mathrm{C} / \mathrm{H}$ is the same both in the initial and desulphurized coal by the formula:

$G_{\mathrm{H}_{2} \mathrm{O}}=\left(G_{\mathrm{CO}}+G_{\mathrm{CO}_{2}}\right) \cdot \frac{\mathrm{H}}{\mathrm{C}}$,

where $H=6$ and $C=65 \mathrm{wt} \%$ mean the average content of hydrogen and carbon in lignite.

The thermal effects of reactions were calculated and accepted according to (Ryabov et al. 1977). It is generally accepted that the conversion of pyrite in the lignite to hydrogen sulphide occurs by the given chemical equation:

$\mathrm{FeS}_{2}+\mathrm{H}_{2} \rightarrow \mathrm{H}_{2} \mathrm{~S}+\mathrm{FeS}$

In compiling the heat balance of the process of oxidative desulphurization of coal, the amount of heat, released due to the burning of desulphurized gases after extraction of
$\mathrm{H}_{2} \mathrm{~S}$ was considered. The useful calorific value of desulphurized gases, MJ, was calculated by the standard procedures (Gumenetskyy 2003):

$$
\begin{aligned}
\mathrm{Q}_{\mathrm{k}}= & \frac{\eta \cdot\left(\mathrm{G}_{\mathrm{gas}}-\mathrm{G}_{\mathrm{H}_{2} \mathrm{~S}}\right)}{\rho_{\text {gas }}} \cdot\left(0.358 \cdot \mathrm{CH}_{4}+0.637 \cdot \mathrm{C}_{2} \mathrm{H}_{6}\right. \\
& +0.912 \cdot \mathrm{C}_{3} \mathrm{H}_{8}+0.591 \cdot \mathrm{C}_{2} \mathrm{H}_{4}+0.108 \cdot \mathrm{H}_{2}+0.126 \\
& \cdot \mathrm{CO}),
\end{aligned}
$$

where $\mathrm{G}_{\mathrm{gas}} ; \mathrm{G}_{\mathrm{H}_{2} \mathrm{~S}}$ - the amount of desulphurized gases and hydrogen sulphide, respectively, $\mathrm{kg} ; \rho_{\text {gas }}$ - the density of desulphurized gases, $\mathrm{kg} / \mathrm{m}^{3} ; \eta=0.8$-furnace efficiency; $\mathrm{CH}_{4}, \mathrm{C}_{2} \mathrm{H}_{6}, \mathrm{C}_{3} \mathrm{H}_{8}, \mathrm{C}_{2} \mathrm{H}_{4}, \mathrm{H}_{2}, \mathrm{CO}$-the contents of corresponding constituents in fuel, vol\%.

\section{Results and discussion}

As mentioned above, in the works (Pyshyev et al. 2012b; Gunka and Pyshyev 2014, 2015) detailed studies on the effect of factors and fluid dynamic parameters on the process of oxydesulphurization of lignite were undertaken. These we employed to obtain low-sulphur solid fuel required to reduce sulphur emissions in TPPs. Upon the oxidative desulphurization of lignite, the calorific value increases by $5.0 \%$ (from 22165 to $23284 \mathrm{~kJ} / \mathrm{kg}$ per analytical sample) and by $7.6 \%$ (from 26769 to $28817 \mathrm{~kJ} / \mathrm{kg}$ per organic matter) which is due to the decreasing moisture and increasing carbon content in the organic matter. This altogether and a significant reduction in the sulphur content upon the oxydesulphurization (Gunka and Pyshyev 2014, 2015) makes it possible to anticipate the successful utilization of desulphurized coal in the power industry.

In the process of the lignite oxidative desulphurization, the decomposition of organic matter produces tar. The amount of tar obtainable depends on the process conditions and can be equal to $26 \mathrm{wt} \%$ or approximately $1 / 3$ of the main product amount. It is assumed that the cost of tar if used, for example, as fuel oil, can exceed by several times the price of desulphurized coal. Taking into account the above, the study on the effect of factors on the quality of tar derived from the decomposition of lignite organic matter and on establishing new cost-effective ways of tar application is promising. Therefore, the process conditions were determined that would provide the maximum amount of the decomposition tar of lignite organic matter with the minimum density so that it could be used as the fuel oil or its component. That said, the effect of the oxidant composition (the content of water vapour in the air-steam mixture), temperature, oxidant flow rate (OFR) coupled with duration on the process was investigated. The OFR was calculated as the ratio between the volumetric flow air-steam 
Table 2 Effect of the oxidant composition (other fixed conditions: the temperature $-425{ }^{\circ} \mathrm{C}$; OFR $-2.4 \mathrm{~m}^{3} /(\mathrm{h} \mathrm{kg}$ ); process duration $-15 \mathrm{~min}$ )

\begin{tabular}{|c|c|c|c|c|c|}
\hline $\begin{array}{l}\text { Water vapour content in the } \\
\text { oxidant (vol\%) }\end{array}$ & $\begin{array}{l}\text { Yield of desulphurized } \\
\text { coal }(\mathrm{wt} \%)\end{array}$ & $\begin{array}{l}\text { Yield of tar } \\
(\mathrm{wt} \%)\end{array}$ & $\begin{array}{l}\text { Density at } 20{ }^{\circ} \mathrm{C} \\
\left(\mathrm{kg} / \mathrm{m}^{3}\right)\end{array}$ & $\begin{array}{l}\text { Tar kinematic viscosity at } \\
100{ }^{\circ} \mathrm{C} \text {, SSC }\end{array}$ & $\begin{array}{l}\text { Sulphur content } \\
\text { (wt\%) }\end{array}$ \\
\hline 0 & 50.68 & 17.85 & 1061 & 18.32 & 1.68 \\
\hline 4.5 & 51.12 & 18.26 & 1058 & 18.25 & 1.65 \\
\hline 30 & 54.48 & 23.16 & 1054 & 17.58 & 1.52 \\
\hline 50 & 60.05 & 24.96 & 1050 & 17.02 & 1.41 \\
\hline 70 & 63.08 & 26.58 & 1048 & 16.53 & 1.35 \\
\hline
\end{tabular}

mixture $\left(\mathrm{m}^{3} / \mathrm{h}\right)$ and the coal mass $(\mathrm{kg})$. The results obtainable for the effect of oxidant composition are shown in Table 2.

After analyzing the data in Table 2, it becomes apparent that the water vapour inhibits the combustion reaction. Hence, the yield of the desulphurized coal and tar of organic coal decomposition increases with an increasing amount of the water vapour in the oxidant. As the amount of water vapour in the oxidant increases, the density and kinematic viscosity of decomposition tar of COM are observed to be decreased. The sulphur content in tar is slightly reduced, which indicates a minor effect of water vapour on the reactions where pyritic lignite sulphur converses. Therefore, for the purpose of maximum production of tar from the oxidative treatment of lignite, the further researches were carried out at the content of water vapour 70 vol\%.

The experimental results showing the effect of temperature on the amount and quality of tar of lignite oxidative desulfurization are given in Table 3.

As shown in Table 3, the yield of tar increases dramatically as the temperature is raised to $425^{\circ} \mathrm{C}$. There is also an increase in the density and kinematic viscosity of tar due to decomposition of COM. Hence, the temperature rise is conducive to decomposition reactions of highly condensing organic structures. As for the sulphur content in tar, the content of sulphur decreased with increasing temperature. Accordingly, further researches were conducted at the temperature of $425^{\circ} \mathrm{C}$. The experimental results showing the effect of OFR on the amount and quality of tar of lignite oxidative desulphurization are presented in Table 4.

As shown in Table 4, an increase in OFR was followed by a rise in the tar density and viscosity. This indicates that the increasing OFR contributed to decomposition reactions of highly condensing organic structures. As the multiplicity of oxidant consumption is increased, the sulphur content in the decomposing tar increases as well. At OFR values equal to $2.40 \mathrm{~m}^{3} /(\mathrm{h} \mathrm{kg})$ the yield of tar is relatively high (26.58 wt\%) and continues to rise slightly. Consequently, the value of OFR can be considered optimal.

The experimental results in studying how the process duration influence the yield and quality of tar are given in Table 5.

As the data in Table 5 shows, with the increase in process duration, the tar density and viscosity increased as observed. This indicates that an increase in the passage time of reactions intensifies the decomposition of highly condensing organic structures. As the process duration was increased, the sulphur content of decomposition tar of lignite organic matter declined. At the 15-min duration, a relatively high yield of tar is proved to be attained.

In summary, the optimal conditions for the oxydesulphurization of lignite, in this case, were chosen to ensure the maximum yield of decomposition tar at its relatively low viscosity, density and sulphur content of up to $1.5 \mathrm{wt} \%$. For these reasons, the following conditions were chosen:

Table 3 Effect of temperature (other fixed conditions: the content of water vapour in the oxidant -70 vol\%; OFR $-2.4 \mathrm{~m}^{3} /(\mathrm{h} \mathrm{kg})$; the $\mathrm{process}$ duration $-15 \mathrm{~min}$ )

\begin{tabular}{llllll}
\hline $\begin{array}{l}\text { Temperature } \\
\left({ }^{\circ} \mathrm{C}\right)\end{array}$ & $\begin{array}{l}\text { Yield of desulphurized coal } \\
(\mathrm{wt} \%)\end{array}$ & $\begin{array}{l}\text { Yield of tar } \\
(\mathrm{wt} \%)\end{array}$ & $\begin{array}{l}\text { Density at } 20{ }^{\circ} \mathrm{C} \\
\left(\mathrm{kg} / \mathrm{m}^{3}\right)\end{array}$ & $\begin{array}{l}\text { Tar kinematic viscosity at } \\
100{ }^{\circ} \mathrm{C}, \mathrm{SSC}\end{array}$ & $\begin{array}{l}\text { Sulphur content } \\
(\mathrm{wt} \%)\end{array}$ \\
\hline 350 & 74.97 & 15.31 & 1020 & 14.96 & 1.72 \\
400 & 69.17 & 21.23 & 1033 & 15.32 & 1.53 \\
425 & 63.08 & 26.58 & 1048 & 16.53 & 1.35 \\
450 & 55.91 & 26.66 & 1055 & 16.98 & 1.27 \\
475 & 48.55 & 26.75 & 1061 & 17.32 & 1.22 \\
500 & 43.94 & 26.83 & 1073 & 17.48 & 1.20 \\
\hline
\end{tabular}


Table 4 OFR effect (other fixed conditions: the content of water vapour in the oxidant -70 vol\%; the temperature- $425{ }^{\circ} \mathrm{C}$; the process duration $-15 \mathrm{~min})$

\begin{tabular}{llllll}
\hline $\begin{array}{l}\text { OFR-2.4 }\left[\mathrm{m}^{3} /\right. \\
(\mathrm{h} \mathrm{kg})]\end{array}$ & $\begin{array}{l}\text { Yield of desulphurized coal } \\
(\mathrm{wt} \%)\end{array}$ & $\begin{array}{l}\text { Yield of tar } \\
(\mathrm{wt} \%)\end{array}$ & $\begin{array}{l}\text { Density at } 2{ }^{\circ} \mathrm{C} \\
\left(\mathrm{kg} / \mathrm{m}^{3}\right)\end{array}$ & $\begin{array}{l}\text { Tar kinematic viscosity at } \\
100{ }^{\circ} \mathrm{C}, \mathrm{SSC}\end{array}$ & $\begin{array}{l}\text { Sulphur content } \\
(\mathrm{wt} \%)\end{array}$ \\
\hline 1.20 & 61.61 & 17.18 & 1036 & 15.87 & 1.18 \\
1.80 & 62.13 & 21.12 & 1040 & 16.11 & 1.27 \\
2.40 & 63.08 & 26.58 & 1048 & 16.53 & 1.35 \\
3.60 & 63.25 & 26.96 & 1054 & 16.85 & 1.62 \\
4.80 & 63.52 & 27.41 & 1066 & 17.02 & 1.88 \\
\hline
\end{tabular}

Table 5 Effect of duration (other fixed conditions: the content of water vapour in the oxidant-70 vol\%; the temperature- $425{ }^{\circ} \mathrm{C}$; OFR— $\left.2.4 \mathrm{~m}^{3} /(\mathrm{h} \mathrm{kg})\right)$

\begin{tabular}{llllll}
\hline $\begin{array}{l}\text { Duration } \\
(\mathrm{min})\end{array}$ & $\begin{array}{l}\text { Yield of desulphurized coal } \\
(\mathrm{wt} \%)\end{array}$ & $\begin{array}{l}\text { Yield of tar } \\
(\mathrm{wt} \%)\end{array}$ & $\begin{array}{l}\text { Density at } 20{ }^{\circ} \mathrm{C}(\mathrm{kg} / \\
\left.\mathrm{m}^{3}\right)\end{array}$ & $\begin{array}{l}\text { Tar kinematic viscosity at } \\
100{ }^{\circ} \mathrm{C}, \mathrm{sSc}\end{array}$ & $\begin{array}{l}\text { Sulphur content } \\
(\mathrm{wt} \%)\end{array}$ \\
\hline 5 & 74.21 & 15.58 & 1032 & 14.12 & 1.82 \\
10 & 69.12 & 20.62 & 1040 & 15.64 & 1.52 \\
15 & 63.08 & 26.58 & 1048 & 16.53 & 1.35 \\
20 & 56.12 & 27.12 & 1055 & 16.78 & 1.3 \\
30 & 51.42 & 27.73 & 1061 & 17.18 & 1.28 \\
\hline
\end{tabular}

- OLR-0.025 m/s;

- Water vapour content in the oxidant-70 vol\%;

- Temperature- $425{ }^{\circ} \mathrm{C}$;

- OFR c $2.4 \mathrm{~m}^{3} /(\mathrm{h} \mathrm{kg})$;

- Duration-15 min.

The researches highlighted in this article and in Gunka and Pyshyev $(2014,2015)$ have formed the basis for estimations of technological process parameters (primarily, material and heat balances of the processes which are presented in Table 6). During calculations of heat balances, the values of heat (expressed in $\mathrm{MJ}$ ) reported and consumed in-process are relative to $100 \mathrm{~kg}$ of initial coal. The calculations were made for three possible areas the process of oxidative desulphurization of lignite can occur:

(1) Power generation: achievement of the maximum degree of desulphurization of coal at minimum energy costs. It was performed without adding water vapour to the air (the mean content of water vapour in the relatively dry air accounted for 4.5 vol\%).

(2) Power generation and technology: aiming at producing the maximally possible degree of sulphur removal and the highest content of $\mathrm{H}_{2} \mathrm{~S}$ in desulphurized gases. It was conducted by adding water vapour to the air (the content of water vapour in the oxidant was 50 vol\%).

(3) Technology: aiming at producing the maximum degree of decomposition tar and the satisfactory degree of sulphur removal $(>50 \%)$. It was executed by adding water vapour to the air (the content of water vapour in the oxidant was 70 vol\%).

Calculations were made for cases in which the processes were conducted under optimal conditions that are above the specified technology direction. The optimal conditions for realization of the process by other two directions are reported in Gunka and Pyshyev $(2014,2015)$ and are found to be:

- Power generation direction:

- OLR-0.01875 m/s;

- The content of water vapour in the oxidant-4.5 vol\%;

- Temperature-425 ${ }^{\circ} \mathrm{C}$;

- OFR-0.6 m³ $/(\mathrm{h} \mathrm{kg})$;

- Duration-10 min;

- Power generation and technology direction:

- OLR-0.01875 m/s;

- The content of water vapour in the oxidant50.0 vol\%;

- Temperature- $425^{\circ} \mathrm{C}$;

- OFR- $0.6 \mathrm{~m}^{3} /(\mathrm{h} \mathrm{kg})$;

- Duration-10 min.

As the given calculations show, the amount of heat, emitted as a result of reactions that proceed during the process and generated due to the afterburning of desulphurized gases. This is sufficient to heat the coal to the temperature of reaction and oxidant preparation. Hence, the residual heat equivalent to $0.36-0.77 \mathrm{MJ} / \mathrm{kg}$ of coal can be used to generate water vapour. 
Table 6 Material and heat balances of the lignite oxidative desulphurization

\begin{tabular}{|c|c|c|c|c|c|}
\hline Articles & $\begin{array}{l}\mathrm{t} \\
\left({ }^{\circ} \mathrm{C}\right)\end{array}$ & $\begin{array}{l}\text { Phase } \\
\text { condition }\end{array}$ & $\begin{array}{l}\text { Enthalpy }(\mathrm{kJ} / \\
\mathrm{kg})\end{array}$ & $\begin{array}{l}\text { Amount, } G_{\mathrm{i}} \\
(\mathrm{kg})\end{array}$ & $\begin{array}{l}\text { Heat amount } \\
\text { (MJ) }\end{array}$ \\
\hline \multicolumn{6}{|l|}{4.5 vol\% of water vapour in the oxidant (power generation direction) } \\
\hline \multicolumn{6}{|l|}{ Feeding } \\
\hline 1. Lignite & 20 & $\mathrm{~S}$ & 29.00 & 100.00 & 2.90 \\
\hline 2. Air & 20 & $\mathrm{G}$ & 20.10 & 12.35 & 0.25 \\
\hline 3. Water & 20 & $\mathrm{~L}$ & 83.80 & 0.36 & 0.03 \\
\hline 4. Heat of reaction & - & - & - & - & 81.71 \\
\hline $\begin{array}{l}\text { 5. The useful heat of combustion of desulphurized gases after } \mathrm{H}_{2} \mathrm{~S} \\
\text { removal }\end{array}$ & - & - & - & - & 42.06 \\
\hline Total & - & - & - & - & 126.95 \\
\hline \multicolumn{6}{|l|}{ Received } \\
\hline 1. Desulphurized lignite & 50 & $\mathrm{~S}$ & 70.00 & 55.41 & 3.88 \\
\hline 2. Decomposition tar & 150 & $\mathrm{~L}$ & 298.81 & 18.85 & 5.63 \\
\hline 3. Water vapor & 150 & $\mathrm{~V}$ & 2778.35 & $12.06^{\mathrm{b}}$ & 33.50 \\
\hline 4. Desulphurized gases & 150 & $\mathrm{G}$ & 158.35 & 19.52 & 3.09 \\
\hline 5. Heat residue & - & - & - & - & $76.76^{\mathrm{c}}$ \\
\hline 6. Losses & - & - & - & - & $4.09^{\mathrm{a}}$ \\
\hline Total & - & - & - & - & 126.95 \\
\hline \multicolumn{6}{|c|}{50 vol\% water vapour in the oxidant (power generation and technology direction) } \\
\hline \multicolumn{6}{|l|}{ Feeding } \\
\hline 1. Lignite & 20 & $\mathrm{~S}$ & 29.00 & 100.00 & 2.90 \\
\hline 2. Air & 20 & $\mathrm{G}$ & 20.10 & 6.47 & 0.13 \\
\hline 3. Water & 20 & $\mathrm{~L}$ & 83.80 & 4.02 & 0.34 \\
\hline 4. Heat of reaction & - & - & - & - & 53.11 \\
\hline $\begin{array}{l}\text { 5. The useful heat of combustion of desulphurized gases after } \mathrm{H}_{2} \mathrm{~S} \\
\text { removal }\end{array}$ & - & - & - & - & 37.60 \\
\hline Total & - & - & - & - & 94.08 \\
\hline \multicolumn{6}{|l|}{ Received } \\
\hline 1. Desulpharized lignite & 50 & $\mathrm{~S}$ & 70.00 & 61.06 & 4.27 \\
\hline 2. Decomposition tar & 150 & $\mathrm{~L}$ & 298.81 & 20.65 & 6.17 \\
\hline 3. Water vapor & 150 & $\mathrm{~V}$ & 2778.35 & $14.86^{\mathrm{b}}$ & 41.29 \\
\hline 4. Desulphurized gases & 150 & $\mathrm{G}$ & 161.37 & 12.38 & 2.00 \\
\hline 5. Heat residue & - & - & - & - & $35.64^{\mathrm{c}}$ \\
\hline 6. Losses & - & - & - & - & $4.70^{\mathrm{a}}$ \\
\hline Total & - & - & - & - & 94.08 \\
\hline \multicolumn{6}{|l|}{70 vol\% water vapour in the oxidant (technology direction) } \\
\hline \multicolumn{6}{|l|}{ Feeding } \\
\hline 1. Lignite & 20 & $\mathrm{~S}$ & 29.00 & 100.00 & 2.90 \\
\hline 2. Air & 20 & $\mathrm{G}$ & 20.10 & 23.27 & 0.47 \\
\hline 3. Water & 20 & $\mathrm{~L}$ & 83.80 & 33.75 & 2.83 \\
\hline 4. Heat of reaction & - & - & - & - & 92.44 \\
\hline $\begin{array}{l}\text { 5. The useful heat of combustion of desulphurized gases after } \mathrm{H}_{2} \mathrm{~S} \\
\text { removal }\end{array}$ & - & - & - & - & 27.17 \\
\hline Total & - & - & - & - & 125.81 \\
\hline \multicolumn{6}{|l|}{ Received } \\
\hline 1. Desulphurized lignite & 50 & $\mathrm{~S}$ & 70.00 & 63.15 & 4.42 \\
\hline 2. Decomposition tar & 150 & $\mathrm{~L}$ & 298.81 & 26.58 & 7.94 \\
\hline 3. Water vapor & 150 & $\mathrm{~V}$ & 2778.35 & $44.53^{\mathrm{b}}$ & 123.71 \\
\hline 4. Desulphurized gases & 150 & G & 154.21 & 29.14 & 4.49 \\
\hline
\end{tabular}


Table 6 continued

\begin{tabular}{|c|c|c|c|c|c|}
\hline Articles & $\begin{array}{l}\mathrm{t} \\
\left({ }^{\circ} \mathrm{C}\right)\end{array}$ & $\begin{array}{l}\text { Phase } \\
\text { condition }\end{array}$ & $\begin{array}{l}\text { Enthalpy (kJ/ } \\
\mathrm{kg})\end{array}$ & $\begin{array}{l}\text { Amount, } G_{\mathrm{i}} \\
(\mathrm{kg})\end{array}$ & $\begin{array}{l}\text { Heat amount } \\
\text { (MJ) }\end{array}$ \\
\hline 5. Heat residue & - & - & - & - & $-21.05^{\mathrm{d}}$ \\
\hline 6. Losses & - & - & - & - & $6.29^{\mathrm{a}}$ \\
\hline Total & - & - & - & - & 125.81 \\
\hline
\end{tabular}

${ }^{a}$ Losses into the environment were taken in the amount of $5 \%$ of the reaction heat

${ }^{\mathrm{b}}$ Amount of water vapour to be fed with the oxidant and formed due to a decrease in coal moisture

${ }^{\mathrm{c}}$ Heat amount released from the set-up

${ }^{\mathrm{d}}$ Heat amount that needs to be additionally provided to the set-up, for instance, by burning the part of tar or desulphurized coal

The results of the material balance confirm that during the lignite desulphurization the following is obtained:

- $55.4 \%-63.1 \mathrm{wt} \%$ relative to the feedstock of desulphurized coal;

- $18.9 \%-26.6 \mathrm{wt} \%$ relative to the feedstock of decomposition tar;

- $12.4 \%-29.1 \mathrm{wt} \%$ relative to the feedstock of desulphurized gases.

The characteristics of desulphurized lignite and key technological process parameters are given in Tables 7 and 8.

The data available shows that during the desulphurization of lignite the total sulphur content can be reduced, on average, only by $3.0 \mathrm{wt} \%$ (Table 7). Accordingly, the degrees of total sulphur removal are $29.4 \%-31.8 \%$ (Table 8). This is due to the abnormally high content of organic sulphur in feed coal, which remained virtually unchanged throughout the process. Furthermore, the low yield of desulphurized coal was caused by the high moisture content in the feedstock and high reactivity typical of lignite organic matter. However, if assuming that all the hydrogen sulphide contained in desulphurized gases will be removed or converted to sulphur, the degree of conversion of total sulphur will be equal to the level of reducing environmental pollution. We can, therefore, assert that the method proposed allows emissions of sulphur compounds to the atmosphere during combustion of lignite be reduced, on average, by $53.5 \%-56.0 \%$.
As noted above, the oxidative desulphurization of lignite produces volatile organic compounds that when condensed from a paste-like or semi-liquid brown substance (a decomposition tar). The tar derived from desulphurization of lignite resembles furnace fuel oil in appearance. So research into its quality was done in view of the perspective to be utilized as fuel components.

Before analysis, coal solids were filtered from the tar produced during the technologically performed process. Upon filtration, a range of analyses of quality parameters of decomposition tar of lignite organic matter was made, which are presented in Table 9. For conducting a comparative analysis, the standard requirements for furnace fuel oil of "100" mark and marine high-viscosity fuel are given in Table 9.

After analysing the results obtained (Table 9), it can be concluded that against all the characteristics of lignite tar after oxidative purification complies with the standard for furnace fuel oil of "100" mark and can, therefore, be used as fuel. Given the slight differences between the tar parameters and the requirements of marine high-viscosity fuel, it can be argued that tar can also be used as a component of the given type of fuel.

Since coal is a natural macromolecular aromatic compound, it can be assumed that the tar from the decomposition of lignite organic matter may also include aromatic structures and surface-active substances that can enhance the adhesive and plastic properties of bitumens. Based on the foregoing and considering the low relative viscosity of

Table 7 Characteristic of desulphurized lignite

\begin{tabular}{|c|c|c|c|c|c|c|}
\hline \multirow[t]{2}{*}{ Moisture, $\mathrm{W}^{\mathrm{af}}(\mathrm{wt} \%)$} & \multirow[t]{2}{*}{ Ash, $A^{d}(w t \%)$} & \multirow[t]{2}{*}{ Volatility, $V^{\text {daf }}(w t \%)$} & \multicolumn{4}{|c|}{ Sulphur content (wt\%) } \\
\hline & & & Total, $S_{t}^{d}$ & Pyritic, $S_{p}^{d}$ & Organic, $S_{0}^{d}$ & Sulphate, $\mathrm{S}_{\mathrm{SO}_{4}}^{\mathrm{d}}$ \\
\hline \multicolumn{7}{|c|}{4.5 vol\% water vapour in the oxidant (power generation direction) } \\
\hline 2.3 & 14.4 & 44.3 & 3.02 & 0.49 & 0.29 & 2.24 \\
\hline \multicolumn{7}{|c|}{50 vol\% water vapour in the oxidant (power generation and technology direction) } \\
\hline 3.0 & 13.4 & 46.9 & 2.92 & 0.46 & 0.31 & 2.15 \\
\hline \multicolumn{7}{|c|}{70 vol\% water vapour in the oxidant (technology direction) } \\
\hline 4.1 & 14.0 & 39.5 & 2.99 & 0.38 & 0.32 & 2.29 \\
\hline
\end{tabular}


Table 8 Lignite sulphur removal and conversion degrees

\begin{tabular}{|c|c|c|c|c|}
\hline \multirow[t]{2}{*}{ Water vapour in the oxidant (vol\%) } & \multicolumn{2}{|c|}{ Removal degree of sulphur, RDS (\%) } & \multicolumn{2}{|c|}{ Sulphur conversion, SC (\%) } \\
\hline & Total & Pyritic & Total & Pyritic \\
\hline 4.5 (Power generation direction) & 29.4 & 76.7 & 56.0 & 85.5 \\
\hline 50 (Power generation and technology direction) & 31.8 & 78.1 & 53.5 & 85.1 \\
\hline 70 (Technology direction) & 30.1 & 81.90 & 54.2 & 95.09 \\
\hline
\end{tabular}

Table 9 Comparison between the quality parameters of lignite tar with the requirements for furnace fuel oil of " 100 " mark and marine high viscosity fuel

\begin{tabular}{|c|c|c|c|c|}
\hline \multirow[t]{2}{*}{ Name of parameter } & \multicolumn{2}{|l|}{ Requirements for } & \multirow{2}{*}{$\begin{array}{l}\text { Quality parameters of } \\
\text { decomposition tar }\end{array}$} & \multirow[t]{2}{*}{ Procedure $^{\mathrm{a}}$} \\
\hline & $\begin{array}{l}\text { Furnace fuel oil of "100" mark } \\
\text { according to DSTU 4058:2001 }\end{array}$ & $\begin{array}{l}\text { Marine high-viscosity fuel } \\
\text { according to TU38.1011314-90 }\end{array}$ & & \\
\hline $\begin{array}{l}\text { Relative viscosity at } \\
80{ }^{\circ} \mathrm{C} \text {, nominal } \\
\text { degrees }\end{array}$ & $\leq 16.0$ & $\leq 16.0$ & 4.6 & $\begin{array}{l}\text { GOST 33:2000 } \\
\quad \text { (ISO 3104:1994) }\end{array}$ \\
\hline $\begin{array}{l}\text { Kinematic viscosity at } \\
80^{\circ} \mathrm{C}, \mathrm{cSt}\end{array}$ & $\leq 118.0$ & $\leq 118.0$ & 33.1 & \\
\hline Ash content (wt\%) & $\leq 0.14$ & $\leq 0.15$ & 0.09 & GOST 1461:1975 \\
\hline $\begin{array}{l}\text { Density at } 20{ }^{\circ} \mathrm{C}(\mathrm{kg} / \\
\left.\mathrm{m}^{3}\right)\end{array}$ & Not rated & 1015 & 1048 & GOST 3900:1985 \\
\hline Sulphur content (wt\%) & $\leq 2.0$ & $\leq 5.0$ & 1.3 & GOST 1437:1975 \\
\hline $\begin{array}{l}\text { Conradson carbon } \\
\text { residue (wt } \% \text { ) }\end{array}$ & Not rated & 22.0 & 9.5 & $\begin{array}{r}\text { GOST 19932:1999 } \\
\text { (ISO 6615:1993) }\end{array}$ \\
\hline Water weight (wt $\%$ ) & $\leq 1.0$ & Not rated & 0.8 & GOST 2477:1965 \\
\hline $\begin{array}{l}\text { Open cup flash point } \\
\left({ }^{\circ} \mathrm{C}\right)\end{array}$ & $\geq 110$ & $\geq 100$ & 114 & GOST 4333:1987 \\
\hline Chilling point $\left({ }^{\circ} \mathrm{C}\right)$ & $\leq 42$ & $\leq 25$ & 42 & GOST 20287:1991 \\
\hline
\end{tabular}

${ }^{\mathrm{a}} \mathrm{DSTU}$, TU and GOST refer to Ukrainian national standards

decomposition tar, the studies were carried out on the use of this tar as a plasticizer for petroleum-based bitumens.

Coumarone-indene resin (CIR) modified bitumens were used for research. It was found in the works (Pyshyev et al. 2016, 2017c) that the addition of CIR to bitumen allows the softening point of bitumens to be significantly increased thereby significantly enhancing its adhesive properties. It is worth noting that this tar is priced noticeably less than the most prevalent industrial polymer additives (for example, SBS type). On the contrary, adding CIR markedly worsens the plastic properties of the bitumen (penetration and ductility). So for the improvement of these properties of polymer-modified bitumens, it was suggested to utilize tar formed due to decomposition of lignite organic matter. The experimental results are shown in Table 10.

As the experimental data (Table 10) shows, while modifying bitumen with CIR, the softening point increases significantly, however, the plastic properties (depth of needle penetration and extensibility) decline. The addition of plasticizer (decomposition tar) facilitates improvements of bitumen plastic properties, though this almost does not lead to a decrease in the softening point. Increasing the amount of plasticizer leads to an increase in the penetration and a decrease in the ductility of the mixture. Therefore, the optimal content of plasticizer in the mixture is $9 \mathrm{wt} \%$ (with the amount of $7 \mathrm{wt} \%$ modifier), which makes it possible to obtain PMB that by main characteristics is in compliance with the regulation documents for polymermodified bitumens.

It should be noted that the use of tar formed as a plasticizer from lignite decomposition allows the adhesion of BMP not to diminish. Correspondingly, the BMP obtained has excellent adhesive properties (providing a strong bond of the binder with the mineral material), regardless of the ratio of components.

To determine possible ways of the disposition of desulphurized, the gases were examined by the chromatographic analysis (Table 11).

The hydrogen sulphide produced by lignite oxydesulphurization has a desulphurized gas content of 5.7\%12.5 vol\% (Table 11). This can be concentrated using the traditional chemisorption or absorption methods (Javorskyi 
Table 10 Research on lignite tar as a PMBs plasticizer

\begin{tabular}{|c|c|c|c|c|c|c|}
\hline \multicolumn{3}{|l|}{ Blend composition (wt\%) } & \multicolumn{4}{|l|}{ Characteristics of PMBs } \\
\hline Bitumen & CIR & Plasticizer & $\begin{array}{l}\text { Softening point (ball and } \\
\text { ring method) according to } \\
\text { GOST } 11506: 1973\left({ }^{\circ} \mathrm{C}\right)\end{array}$ & $\begin{array}{l}\text { Ductility at } 25^{\circ} \mathrm{C} \\
\text { according to GOST } \\
11505: 1975(\mathrm{~cm})\end{array}$ & $\begin{array}{l}\text { Penetration at } 25^{\circ} \mathrm{C} \\
\text { according to GOST } \\
11501: 1978 \\
\left(\mathrm{~m} \times 10^{-4}\right)\end{array}$ & $\begin{array}{l}\text { Adhesion to glass } \\
\text { according to DSTU } \\
\text { BV.2.7-81:1998 (\%) }\end{array}$ \\
\hline 100 & 0 & 0 & 47 & 75 & 62 & 46 \\
\hline 93 & & 0 & 52 & 36 & 38 & 100 \\
\hline 86 & & 7 & 52 & 40 & 42 & 100 \\
\hline 85 & 7 & 8 & 52 & 36 & 47 & 100 \\
\hline 84 & & 9 & 52 & 28 & 62 & 100 \\
\hline 83 & & 10 & 51 & 27 & 65 & 100 \\
\hline $\begin{array}{l}\text { Standard for BMP 60/90- } \\
52 \text { bitumen according } \\
\text { to DSTU BV.2.7- } \\
\text { 135:2007 }\end{array}$ & & & $52-54$ & $\geq 25$ & $61-90$ & $\geq 75$ \\
\hline
\end{tabular}

DSTU and GOST refer to Ukrainian national standards

Table 11 Gases composition of desulphurized lignite

\begin{tabular}{|c|c|c|c|}
\hline \multirow[t]{2}{*}{ Component } & \multicolumn{3}{|l|}{ Water vapour in the oxidant (vol\%) } \\
\hline & 4.5 (Power generation direction) & 50 (Power generation and technology direction) & 70 (Technology direction) \\
\hline $\mathrm{H}_{2} \mathrm{~S}$ & 8.01 & 12.49 & 5.71 \\
\hline $\mathrm{H}_{2}$ & 0.79 & 1.34 & $-{ }^{\mathrm{a}}$ \\
\hline $\mathrm{CH}_{4}$ & 2.68 & 3.28 & 1.12 \\
\hline $\mathrm{C}_{2} \mathrm{H}_{4}$ & 0.68 & 0.98 & 0.31 \\
\hline $\mathrm{C}_{2} \mathrm{H}_{6}$ & 0.93 & 1.56 & 0.36 \\
\hline $\mathrm{C}_{3}$ & 1.23 & 1.97 & 0.51 \\
\hline $\mathrm{CO}$ & 5.51 & 6.45 & 2.81 \\
\hline $\mathrm{CO}_{2}$ & 23.54 & 24.99 & 18.12 \\
\hline $\mathrm{O}_{2}$ & 1.23 & 0.65 & 66.66 \\
\hline $\mathrm{N}_{2}$ & 54.76 & 45.76 & 3.62 \\
\hline $\mathrm{Ar}$ & 0.64 & 0.53 & 0.78 \\
\hline
\end{tabular}

${ }^{\mathrm{a}}$ The content of $\mathrm{H}_{2}$ was not determined

2010; Grebenyuk et al. 2002). The concentrated $\mathrm{H}_{2} \mathrm{~S}$ is commonly used to produce sulphuric acid or sulphur in the traditional Claus process (Grunvald 1992). However, in cases where the content of hydrogen sulphide in gases is greater than $5 \mathrm{vol} \%$, it is a good practice to convert it directly to sulphur by known methods (Javorskyi 2010; Grebenyuk et al. 2002).

The researches outlined in this article and in Gunka and Pyshyev $(2014,2015)$ have underpinned a block schematic diagram of the process of desulphurization of lignite by the oxidation method.

The technology of oxydesulpurization can be implemented into production if the following stages are to be reached:

- Heating the oxidant and initial coal to the temperature of the process;
- Making a reliable contact between the oxidant and coal in the reaction zone;

- Heat regeneration of desulphurized gases;

- Separation of gases from decomposition tar;

- Direct discharging of hot coal into boiler units of the second stage of combustion (in the case of the process at a steam power plant) or of cooled desulphurized coal (if necessary, coal can be transported to a consumer);

- Purification (filtering) of tar from solid particles or tar application without being filtered as plasticizers for modified bitumen. Based on the foregoing, a block schematic diagram of lignite oxidative desulphurization is suggested (Fig. 1). 


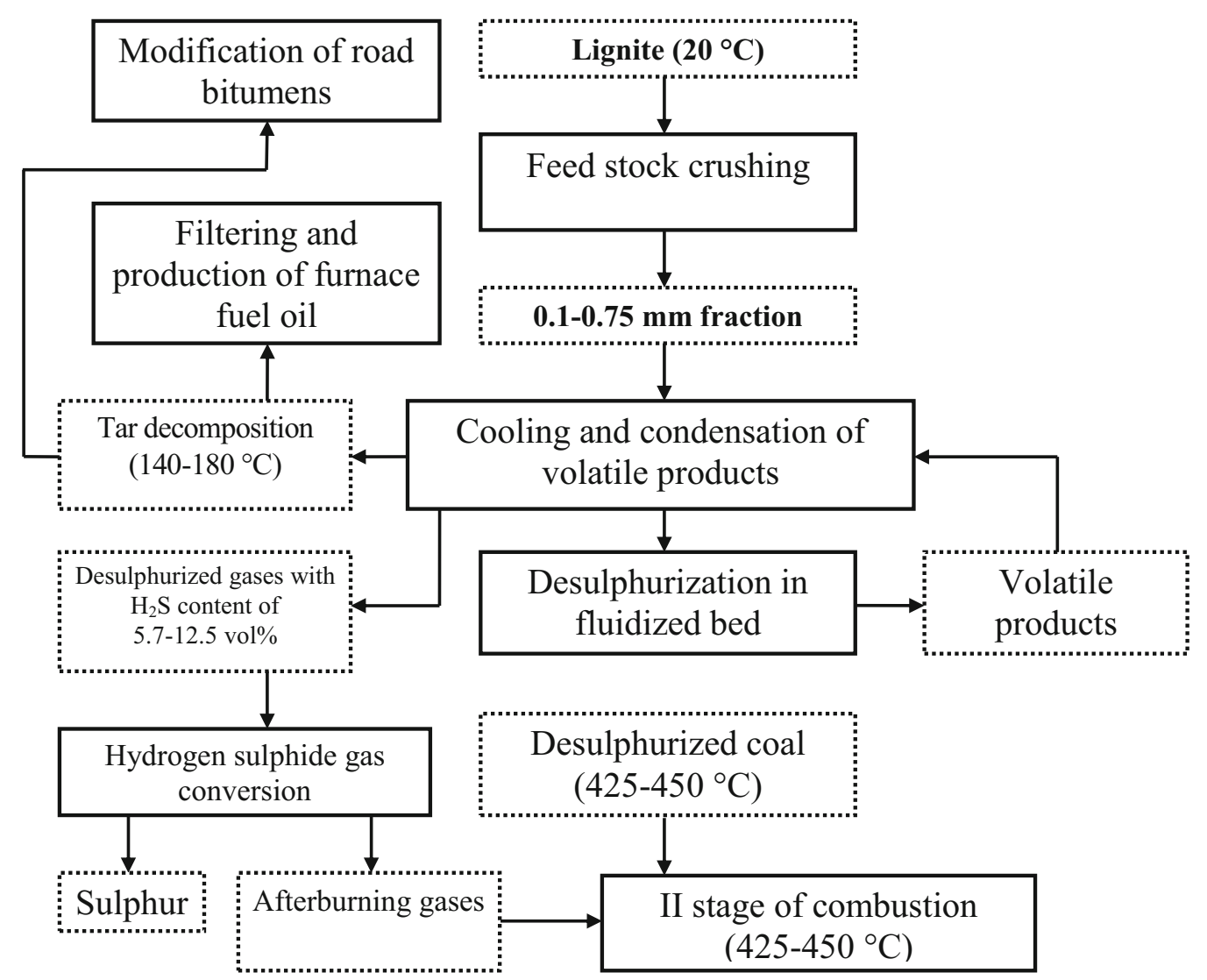

Fig. 1 Block schematic diagram of the oxidative desulphurization of lignite

Lignite is crushed to the size of $0.1-0.75 \mathrm{~mm}$. The crushed coal is fed to the heat exchanger, where it is heated to $220-300{ }^{\circ} \mathrm{C}$ due to the cooling of volatile products from desulphurization. The heated lignite enters a fluidized-bed reactor, coming in contact with the oxidant at $425-450{ }^{\circ} \mathrm{C}$. When the oxidant contacts with lignite, sulphur is converted to $\mathrm{H}_{2} \mathrm{~S}$, leaving the reaction zone together with other gases and vapours.

From the reaction zone the water vapour, desulphurized gases and tar derived from decomposition come into the heat exchanger where they undergo condensation and cooling to the temperatures of $140-180{ }^{\circ} \mathrm{C}$. Condensed lignite tar after being filtered from mechanical impurities can be utilized as a component of furnace fuel oil or as a plasticizer in the modification of petroleum-based road bitumen. Desulfurized coal leaving the reaction zone enters directly into the boiler units of the TPP (II stage of combustion).

The desulfurized gases of lignite are conversed to produce sulphur. The desulfurized gases, after $\mathrm{H}_{2} \mathrm{~S}$ can be removed and subjected to secondary combustion.

\section{Conclusions}

Three technological fields of applying the oxidative desulphurization of Ukrainian high-sulphur lignite, i.e. power generation, power generation and technology, and technology field of application-have been suggested. The optimal conditions of each area are as follows:

(1) Power generation: OLR $-0.01875 \mathrm{~m} / \mathrm{s}$; the content of water vapour in the oxidant $-4.5 \mathrm{vol} \%$; the temperature $-425{ }^{\circ} \mathrm{C} ; \quad$ OFR $-0.6 \mathrm{~m}^{3} /(\mathrm{h} \mathrm{kg}) ; \quad$ the duration-10 $\mathrm{min}$;

(2) Power generation and technology: OLR$0.01875 \mathrm{~m} / \mathrm{s}$; the content of water vapour in the oxidant -50.0 vol\%; the temperature $-425{ }^{\circ} \mathrm{C}$; OFR $-0.6 \mathrm{~m}^{3} /(\mathrm{h} \mathrm{kg})$; the duration-10 $\mathrm{min}$.

(3) Technology: OLR- $0.025 \mathrm{~m} / \mathrm{s}$; the content of water vapour in the oxidant-70 vol\%; the temperature$425^{\circ} \mathrm{C}$; OFR $-2.4 \mathrm{~m}^{3} /(\mathrm{h} \mathrm{kg})$; the duration-15 min.

The desulphurization process yields $18.85 \%-26.58 \mathrm{wt} \%$ tar derived from decomposition with respect to the feedstock. In terms of the indicators, the tar meets the requirements for furnace fuel oil based on the "100" mark. 
However, this furnace fuel oil is much more expensive than lignite. The decomposed tar can also be used as a plasticizer of modified petroleum-based bitumen.

When lignite is desulphurized by the oxidation method, hydrogen sulphide is produced whose content in the desulphurized gases contributes to $5.7 \%-12.5$ vol\%. Hydrogen sulphide is feasible to be further concentrated or directly converted to sulphur. The desulphurized gases after the removal of hydrogen sulphide are required to be reheated for obtaining an additional amount of heat, after which cooled flue gases can be released into the atmosphere.

The flow diagram of the oxydesulphurization of lignite has been proposed. The material and thermal balances of the processes have been calculated. It has been demonstrated that implementation of the process directly at steam power plants will help reduce emissions of sulphur compounds into the air basin during the combustion of lignite on average by $53.5 \%-56.0 \%$.

Open Access This article is distributed under the terms of the Creative Commons Attribution 4.0 International License (http://crea tivecommons.org/licenses/by/4.0/), which permits unrestricted use, distribution, and reproduction in any medium, provided you give appropriate credit to the original author(s) and the source, provide a link to the Creative Commons license, and indicate if changes were made.

\section{References}

Bratychak M, Gajvanovych V, Brzozowski Z (2004) Hard coal desulphurization and sulphur recovery from it. Ecol Chem Eng 11:59-62

Dolgyi VY, Kaplanets NE, Shvedik PP, Shamalo MD, Dolaya VA (2001) Cadastre of coal seams provided for processing mines and coal industry of Ukraine Government cuts to the characteristic geological, mining conditions and quality of coal. DonCI, Donetsk

Grebenyuk AF, Korobchansky VI, Vlasov GA, Kaufman SI (2002) Capture of chemical products of coking. East Publishing House, Donetsk

Grunvald V (1992) Technology sulfur gas. Moskwa, Khimiya

Gumenetskyy VV (2003) Processes and equipment refineries. Lviv Polytechnic National University, Lviv

Gunka V, Pyshyev S (2014) Lignite oxidative desulphurization: notice 1. Process condition selection. Int $\mathbf{J}$ Coal Sci Technol 1(1):62-69

Gunka V, Pyshyev S (2015) Lignite oxidative desulphurization. Notice 2: effects of process parameters. Int J Coal Sci Technol 2(3):196-201
https://www.bgr.bund.de/EN/Themen/Energie/Downloads/energiestu die_2016_en.pdf?_blob=publicationFile $\& v=2$

https://www.worldcoal.org/sites/default/files/resources_files/Coal\% 20Facts\%202015.pdf http://www.eea.europa.eu/data-and-maps/ indicators/eea-32-sulphur-dioxide-so2-emissions-1/assessment-3

Javorskyi VT (2010) The technology of sulfur and sulfuric acid. Lvivska Politekhnika, Lviv

Pysh'yev S, Gayvanovych V, Pattek-Janczyk A, Stanek J (2004) Oxidative desulphurisation of sulphur rich coal. Fuel 9:1117-1122

Pysh'yev S, Gunka V, Bratychak M, Grytsenko Y (2011) Kinetic regularities of high-sulphuric brown coal oxidative desulphurization. Chem Chem Technol 1:107-113

Pysh'yev S, Bilushchak H, Gunka V (2012) Optimization of oxidation desulphurization of power-generating coal. Chem Chem Technol $1: 105-111$

Pyshyev S, Hayvanovych V (1996) Laboratory plant of coal desulphurization via oxidation method. Sci Present Lviv Polytech State Univ 298:96-98

Pyshyev S, Gunka V, Astakhova O, Prysiazhnyi Y, Bratychak M (2012a) Effect of coal quality on its desulphurization 1. Influence of the organic matter. Chem Chem Technol 6(4):443-450

Pyshyev S, Gunka V, Prysiazhnyi Y, Shevchuk K, Pattek-Janczyk A (2012b) Study of oxidative desulphurization process of coal with different metamorphism degrees. $\mathrm{J}$ Fuel Chem Technol 40(2):129-137

Pyshyev S, Iy P, Kochubey V, Miroshnichenko D (2014a) Desulphurization and usage of medium-metamorphized black coal. 2 . Desulphurized coal used as an additive for the production of special types of coke. Chem Chem Technol 8:467-474

Pyshyev S, Iy P, Miroshnichenko D, Bilushchak H, Pyshyeva R (2014b) Desulphurization and usage of medium-metamorphized black coal. 1. Determination of the optimal conditions for oxidative desulphurization. Chem Chem Technol 8:225-234

Pyshyev S, Gunka V, Grytsenko Y, Bratychak M (2016) Polymer modified bitumen: review. Chem Chem Technol 10(4s):631-636

Pyshyev S, Gunka V, Grytsenko Y, Shved M, Kochubei V (2017a) Oil and gas processing products to obtain polymers modified bitumen. Int J Pavement Res Technol 10(4):289-296

Pyshyev S, Prysiazhnyi Y, Shved M, Namiesnik J, Bratychak M (2017b) State of the art in the field of emission reduction of sulphur dioxide produced during coal combustion. Crit Rev Environ Sci Technol 47:2387-2414

Pyshyev S, Prysiazhnyi Y, Shved M, Kułazynski M, Miroshnichenko D (2018) Effect of hydrodynamic parameters on the oxidative desulphurisation of low rank coal. Int J Coal Sci Technol 5(2):213-229

Ryabov VA, Ostroumov MA, Sweet TF (1977) Thermodynamic properties of substances. Chemistry, Moscow

Shevchuk K, Bratychak M, Pysh'yev S, Shyshchak O, Wacławek W (2007) Effect of the temperature and oxidant feed rate on highmetamorphic coal desulphurization process. Ecol Chem Eng 7:747-752

Shved M, Pyshyev S, Prysiazhnyi Y (2017) Effect of oxidant relative flow rate on obtaining raw material for pulverized coal production from high-sulfuric row grade coal. Chem Chem Technol 8:225-234 